\title{
Migratory corridors and foraging hotspots: critical habitats identified for
}

\section{Mediterranean green turtles}

\author{
K. L. Stokes ${ }^{1}$, A. C. Broderick ${ }^{1}$, A. F. Canbolat ${ }^{2}$, O. Candan ${ }^{3}$, W. J. Fuller ${ }^{1,4,5}$, F. Glen ${ }^{6}$, Y. Levy ${ }^{7,8}$, A. F.
} Rees $^{1,9}$, G. Rilov ${ }^{7,10}$, R. T. Snape ${ }^{1,5}$, I. Stott ${ }^{11}$, D. Tchernov ${ }^{7}$ and B. J. Godley ${ }^{1, *}$

${ }^{1}$ Centre for Ecology and Conservation, University of Exeter, Penryn Campus, Cornwall, TR10 9FE, UK

${ }^{2}$ Department of Biology, Hacettepe University, Faculty of Science, 06532 Beytepe, Ankara, Turkey

${ }^{3}$ Department of Biology, Ordu University, Faculty of Sciences and Arts, Cumhuriyet Campus, 52200 Ordu, Turkey

${ }^{4}$ Faculty of Veterinary Medicine, Near East University, Nicosia, North Cyprus, Mersin 10, Turkey

${ }^{5}$ Society for Protection of Turtles, PK65, Kyrenia, North Cyprus, Mersin 10, Turkey

${ }^{6} 16$ Eshton Terrace, Clitheroe, Lancashire, BB7 1BQ, UK

${ }^{7}$ Marine Biology Department, Leon H. Charney School of Marine Sciences, University of Haifa, Haifa 31905, Israel

${ }^{8}$ Israel's Sea Turtle Rescue Centre, Nature \& Parks Authority, Mevoot Yam, Michmoret 40297, Israel

${ }^{9}$ ARCHELON, the Sea Turtle Protection Society of Greece, Solomon S7, GR 10432 Athens, Greece

${ }^{10}$ National Institute of Oceanography, Israel Oceanographic and Limnological Research, PO Box 8030, Haifa 31080, Israel

${ }^{11}$ Environmental \& Sustainability Institute, University of Exeter, Penryn Campus, Cornwall, TR10 9FE, UK

*Author for correspondence (b.j.godley@exeter.ac.uk; 01326 371829)

Running head: green turtle migration

Type: Biodiversity research and reviews.

Abstract: 255 words; Introduction-Acknowledgements: 3,380 words. 


\section{ABSTRACT}

Aim: Levels of sea turtle bycatch in the Mediterranean are thought to be unsustainable. We provide a comprehensive overview of adult green turtle (Chelonia mydas) distribution during nesting, migration and foraging phases, highlighting transitory as well as residential areas of high use in order to facilitate adequate protection for this long-lived, migratory species.

Location: Mediterranean Sea.

Methods: Thirty four females were satellite tracked from breeding grounds in the four countries with major nesting (Cyprus, Turkey, Israel and Syria) for a total of 8,521 (mean: 251) tracking days in a collaborative effort to summarise the most comprehensive set of distribution data thus far assembled for this species in the Mediterranean.

Results: Ten foraging grounds are identified, with two major hotspots in Libya accounting for $>50 \%$ of turtles tracked to conclusive endpoints. The coastlines of Egypt and Libya contain high densities of migrating turtles following the nesting season, particularly July-September, and likely also pre-nesting (April-June). A high-use seasonal pelagic corridor running southwest from Turkey and Cyprus to Egypt is also evident, used by $>50 \%$ of all tracked turtles.

Main conclusions: Bycatch levels and mortality rates for the key foraging areas and high density seasonal pathways identified here are largely unknown, and should be investigated as a priority. We recommend that the Gulf of Sirte in Libya be explored as a potential biodiversity hotspot and considered for proposal as a marine protected area (MPA). Green turtle fidelity to nesting beaches, foraging areas and migratory pathways renders them vulnerable to localised threats but enables targeted mitigation measures and protection.

\section{Keywords}

Chelonia mydas, conservation, density distribution, marine turtle, migration, satellite tracking 


\section{Introduction}

The extensive movements of migratory species pose significant challenges to conservation. Aggregative behaviour and occurrence in geographically disparate habitats can expose migratory groups to diverse and often heightened threats in comparison to non-migratory species. Satellite telemetry studies have been revolutionary in facilitating the identification of widely separated critical habitats, as well as key elements of connectivity such as stopover sites (e.g. cranes, Kanai et al. 2002) and migration corridors (e.g. ungulates, Sawyer et al. 2009). Understanding such migratory connectivity is essential for the successful management of migrant species, not least in the marine realm where populations may be liable to unquantified threats from fisheries in multiple exclusive economic zones (EEZs) and in international waters. Knowledge of the spatiotemporal distribution of highly mobile species in relation to fisheries can be used to inform conservation management protocols, such as gear mitigation or time-area closures (Block et al., 2011).

Marine turtles undergo vast ontogenetic migrations between hatchling, juvenile and adult habitats, and subsequently enter into a cycle of reproductive migrations between foraging areas and suitable nesting beaches that continues throughout adulthood. Life history traits of delayed maturity and longevity leave the group particularly vulnerable when adult mortality levels are elevated (Lewison et al., 2004). Extreme levels of historical harvest have left most populations severely depleted (Seminoff \& Shanker, 2008), and whilst some have shown encouraging rebound capacity (Chaloupka et al., 2008), incidental bycatch in fisheries has impeded recovery in other areas (Lewison et al., 2004). A robust understanding of marine turtle spatial ecology is crucial to the development of effective conservation strategies; satellite telemetry has been used to identify areas of high use (e.g. Shillinger et al. 2008), predict spatial distribution of marine turtle bycatch (e.g. Howell et al. 2008), and evaluate the potential effectiveness of conservation measures (e.g. Maxwell et al. 2011; Scott et al. 2012). Such tracking studies often highlight the need for coordinated, international approaches (e.g. Blumenthal et al. 2006), and in other cases have demonstrated the efficacy of unilateral protection (e.g. Moncada et al. 2012). 
For species with dynamic prey landscapes such as loggerhead (Caretta caretta) and leatherback (Dermochelys coriacea) turtles, habitat modelling may be used to predict spatio-temporal probability of species occurrence (see Witt et al., 2007; Panigada et al., 2008; Zydelis et al., 2011) in order to reduce heavy crossover with fisheries (Howell et al., 2008; Hobday et al., 2010, 2011). Fleet communication programmes have also been successfully implemented to provide real-time reporting of bycatch hotspots, reducing fleetwide levels of bycatch (Gilman et al., 2006b; Alfaro-Shigueto et al., 2012). More static mitigation measures such as marine protected areas and seasonal fisheries closures can be particularly effective for neriticfeeding species with a predictable migratory pattern such as the green turtle (Chelonia mydas), with its high fidelity to nesting beaches, foraging grounds and migratory routes (Limpus et al. 1992; Broderick et al. 2007). Within the Mediterranean, the magnitude of marine turtle bycatch is considered unsustainable (Casale, 2011) and warrants urgent conservation action (Wallace et al., 2010). Two species nest in the region: loggerhead turtles in the central and eastern basins, and green turtles in the eastern (Levantine) basin only. Green turtles in the Mediterranean have suffered extreme declines in the past (Seminoff, 2004) due to heavy overharvesting during the twentieth century (Hornell, 1935; Sella, 1982), and significant rookeries remain only in Turkey, Cyprus and Syria (see Fig. 1 and Table 1; Canbolat, 2004; Rees et al., 2008; Stokes et al., 2014). Previous tracking studies have revealed green turtle foraging grounds within sheltered bays in Turkey, Egypt and Libya (Godley et al., 2002), and have demonstrated female fidelity to these areas both within and across seasons (Broderick et al., 2007). A large-scale tracking project for loggerhead turtles from Zakynthos, Greece, has revealed a more flexible foraging pattern, with cooler, more productive (Zbinden et al., 2011), foraging sites in the north of the central and eastern basins used as seasonal habitat during the summer months only, and year round foraging sites largely in the Gulf of Gabès and Ionian Sea in the central basin (Schofield et al., 2013). Here, comprehensive tracking efforts for green turtles in the Mediterranean are used to identify key foraging habitat and migratory corridors, allowing recommendations for further conservation.

\section{Methods}


Thirty four post-nesting green turtles were tracked between 1998 and 2010 using Platform Terminal Transmitters (PTTs; for details see Table S1) from nesting beaches in northern Cyprus $(n=22)$, Turkey $(n=8)$, Israel $(n=3)$ and Syria $(n=1)$. Transmitters were attached using epoxy resin following the methodology of Godley et al. (2002). Four individuals were tracked during a second post-nesting migration (Broderick et al., 2007); for this analysis, only the first track showing a clear conclusive endpoint from each individual was included. Locations were obtained via the Argos satellite tracking system, and were downloaded, stored and managed using the Satellite Tracking and Analysis Tool (STAT; Coyne \& Godley 2005).

Tracks were processed and mapped using R, ArcGIS, Geospatial Modelling Environment (GME), Quantum GIS (QGIS) and fTools. A Best Daily Location (BDL) filter was applied to the pre-filtered datasets (location classes 0 and $Z$, inferred speeds $>5 \mathrm{~km}^{-1}$ and turning angles $<25^{\circ}$ excluded). Tracks were split into internesting, migrating and foraging stages using displacement plots and visual assessment (see Blumenthal et al., 2006). A post-nesting track was deemed to have conclusively reached a foraging ground if transmissions continued from the end destination for sufficient time to indicate residency (minimum, this study: 27 days). To approximate migratory density, we created a density raster of the number of tracks crossing each cell of a hexagonal grid $\left(0.25^{\circ}\right.$ by $\left.0.25^{\circ}\right)$.

\section{Results}

Transmissions lasted for $251 \pm 184$ days (mean \pm SD; range: $22-714$ ), and 29 out of the 34 turtles were tracked to a definitive foraging ground. Transmissions continued from within foraging grounds for $227 \pm 165$ days (range: 27-650). Turtles from all four countries shared migratory routes and end destination foraging grounds (see Fig. 2).

Ten foraging destinations have been identified in Turkey, Cyprus, Lebanon, Egypt, Libya and Tunisia, ranging from 181 to $2,641 \mathrm{~km}$ minimum swimming distance from the breeding site (mean \pm SD: $1283 \pm 825$ ). Two major foraging grounds in Libya, the Gulf of Bomba (marked C in Fig. 2d, n=8) and Gulf of Sirte (B, n=7), were 
used by $52 \%$ turtles tracked to conclusive end points. An additional foraging ground in the Gulf of Antalya, Turkey $(I, n=4)$, accounts for a further $14 \%$.

Post-nesting migrations lasted 6 - 80 days (mean \pm SD: $36 \pm 23$ ), and took place between $27^{\text {th }}$ June and $12^{\text {th }}$ October (see Fig. 3). The majority of individuals (87\%) completed their return migrations during the months of July - September. Tracked turtles spent an average of $84 \%$ of their migration following coastline $( \pm 11 \%$, range $59-100 \%)$, making use of coastal waters around the eastern basin coastline from Cyprus and Turkey through Syria, Lebanon, Israel and the Gaza Strip to Egypt and across Libya. Particularly high densities of tracks (Fig. 2d) are seen between the Gulfs of Arab (E), Salum (D), Bomba (C) and Sirte (B), with $62 \%$ of all conclusive tracks converging on the approach to the Gulf of Salum ( $n=18), 59 \%$ continuing to Bomba $(n=17)$, and $31 \%$ continuing past Bomba to the Gulf of Sirte $(n=9)$. A high-use pelagic corridor is evident, running southwest from Turkey, across Cyprus, to North Africa. The width of this corridor, as defined by the most central $90 \%$ of tracks $(n=16)$, ranges between $<0.25^{\circ}$ longitude at the westernmost tip of Cyprus and $3.5^{\circ}$ where it meets Egypt. More than half $(53 \%, n=18)$ of all migrants (including those with inconclusive tracks) used this corridor.

Four individuals from Cyprus made secondary migratory movements $(>100 \mathrm{~km})$ after prolonged stays $(51$, 93, 134 and 221 days) in their respective initial foraging grounds. Three of these were tracked to nearby foraging grounds (107, 390 and $475 \mathrm{~km}$ distant), and two later returned to their former foraging grounds after periods of 73 and 129 days.

\section{Discussion}

Green turtles nesting on Mediterranean beaches disperse to widely separated foraging grounds in shallow coastal waters, which they share with conspecifics from other Mediterranean nesting rookeries. This collaborative tracking effort clearly emphasizes the utility of animal tracking in the elucidation of transitory areas of high use as well as residential hotspots. Tracking has revealed a clear migratory pattern, 
highlighting the coastal waters of the Levantine basin and a southwest pelagic corridor as being critical migratory habitat.

The use of a shared pelagic migration corridor by turtles tracked from beaches in Turkey and Cyprus indicates that this pathway is of critical importance during the months surrounding the Mediterranean nesting season. However, there is a disparity between tracking effort and rookery size (Fig. 1), suggesting that further tracking should be directed towards Turkey's major nesting beaches, which are used by the majority of the Mediterranean population. Two turtles tracked by Turkecan and Yerli (2011) from Akyatan, the largest single rookery in the Mediterranean, travelled to sites B and I (Gulfs of Sirte and Antalya) following similar routes as those described here, further highlighting the importance of these sites.

The range of seagrass beds in the Mediterranean is thought to be much reduced (Lipkin et al., 2003); previous damage by fisheries trawling in coastal areas may have contributed to the diminished extent of green turtle foraging grounds in the region. Foraging grounds highlighted in this research, and particularly those with relatively high densities of green turtles, may be indicators of remaining healthy seagrass habitat (Scott et al., 2012). The pelagic corridor identified here follows the direction of deep bathymetric contours and surface currents, which may aid in navigation (see Fig. S2a and b; see also Luschi et al. 1998, Hays et al. 1999). Green turtles may also be congregating along this path as a result of avoidance of cooler waters to the north west of the corridor (see Fig. S2b). Use of pelagic corridors has been observed previously in green turtles in the South Atlantic (Luschi et al., 1998), and in leatherback turtles in the Atlantic (Fossette et al., 2014) and Pacific (Eckert \& Sarti, 1997; Shillinger et al., 2008). Seasonal closures may be appropriate in areas where migratory corridors lead to a high incidence of interactions with fisheries within a restricted season and area; however, such measures are limited to extreme cases due to the substantial associated economic impacts (Gilman et al., 2006a) and likelihood to displace fishing effort elsewhere (Lewison et al., 2004). Threats from fisheries vary with fishing gear type and sea turtle behaviour, and efforts should be made to quantify bycatch levels specific to area and fishing practices, classified by species and age-class. 
The highest-density migratory corridor habitat occurs within the exclusive economic zones (EEZs) of Cyprus, Egypt and Libya (see Fig. S1c), which have estimated marine turtle bycatch rates of around 3,700, 7,000 and 9,700 captures (species not given) per year respectively (Casale, 2011; Nada \& Casale, 2011, see Table S2 for summarised bycatch data). Set netting has the highest mortality rate $(60 \%)$, and makes up $97 \%$ of the turtle bycatch in Cyprus, compared with 41\% in Egypt and just 3\% in Libya, such that the total estimated deaths per year for these countries are more even at 2,200, 2,800, and 2,900 (Casale, 2011). Turkey and Tunisia have higher turtle bycatch figures of 12,900 and 17,600 respectively, resulting in 5,400 and 5,600 estimated turtle deaths per year (Casale, 2011). These rates are derived from official fleet statistics and are therefore minimum values.

During pelagic phases of migration, green turtles are most vulnerable to entanglement in drift nets, of which there remains a sizeable illegal fishery in the Mediterranean despite a total ban (EJF, 2007). Few data are available regarding this Illegal, Unreported and Unregulated (IUU) fishery, but it is not currently known to be a problem in the area of the pelagic corridor described in this study, with most vessels thought to operate in the western basin and the Aegean Sea. The reported incidence of green turtle bycatch in the Mediterranean from pelagic longlines is generally low, although it is impossible to tease apart the effects of improper species identification and a bias of studies to the western basin (Gerosa \& Casale, 1999), where pelagic longlines are responsible for the majority of loggerhead turtle bycatch (Casale, 2011). The largely herbivorous diet of the adult green turtle may render it less susceptible to target baited longline hooks than the sympatric carnivorous loggerhead turtle, although opportunistic carnivory is known to occur (Bjorndal, 1997) and has been detected in young adults in the Mediterranean through stable isotope analysis (Cardona et al., 2010). However, pelagic longlines are responsible for a low proportion (6\%) of estimated turtle deaths in the eastern Mediterranean countries in which green turtles have been observed in this study (for which data are available, Casale 2011; Table S2). 
Coastal aggregation of both fishing vessels and green turtles puts this species at greater risk from nearshore fishing practices, of which bottom trawls, set nets (such as trammel nets and gill nets) and demersal longlines make up $40 \%, 30 \%$ and $20 \%$ respectively of the estimated 52,000 turtle captures (all species) per year (Cyprus, Egypt, Israel, Lebanon, Libya, Syria, Tunisia and Turkey; Casale 2011; Table S2). Bottom-set nets have the greatest impact due to the high mortality rates associated with this gear type, accounting for $50 \%$ of the 20,000 estimated minimum turtle deaths per year (Cyprus, Egypt, Israel, Lebanon, Libya, Syria, Tunisia and Turkey; Casale 2011; Table S2).

Direct take of sea turtles for meat may still be a problem in some areas; there is still an active black market for turtle meat in Alexandria and other Egyptian ports (Nada \& Casale, 2011). In addition, gear damage and perceived competition with local fishermen for depleted fish stocks can lead to intentional killings, evident through stranded carcasses either beheaded or with head trauma (e.g. Nada et al. 2013). Awareness campaigns and fishermen training programmes with repeated contact have proven successful in reducing post-release mortality rates of bycaught turtles, improving cooperation and attitudes towards sea turtles, and reducing motivation for intentional killing (e.g. Oruç 2001; Snape pers. comm.). Additionally, livelihood diversification interventions are needed in areas where poverty enforces reliance on dwindling fish stocks (Nada et al., 2013).

Additional threats to sea turtles in the region arise from oil and gas exploration and boat strike - the pelagic corridor highlighted here is crossed by paths of intense maritime activity, for example (Katsanevakis et al., 2015). Geopolitical instability across the region may cause delays to the successful implementation of new conservation measures, and transboundary collaboration is further complicated by socio-economic conflicts (Katsanevakis et al., 2015).

\section{Recommendations}


The information available regarding marine turtle bycatch in the Levantine basin is spatially vague; further characterisation of turtle bycatch in the eastern Mediterranean should be prioritised as many data gaps exist, particularly from countries on the north African coast (Casale, 2011). Seasonally targeted quantification of bycatch from April to September (see Fig. 3) within transitory corridors of high use may illustrate the true cost of migration for such species. Post-release mortality rates specific to each fishery should also be further investigated due to the high variability in survival depending on practice (e.g. tow durations, soak times) and paucity of information, again from the eastern basin (Casale, 2011). Quantification of bycatch, associated mortality rates and intentional killings within the coastal foraging areas and seasonal migratory pathways highlighted here is urgently required so that remedial action can be implemented where required. Major knowledge gaps exist in relation to species identification of bycatch. Recommendations for fisheries management cannot be made until the threat to green turtles in the eastern basin from bycatch is quantified. Monitoring within the Mediterranean is difficult due to the artisanal nature of much of the fishery (Casale, 2011), but is possible (see Snape et al. 2013).

Networks of marine protected areas (MPAs) can alleviate escalating pressure from fisheries on marine ecosystems, by protecting spawning stocks and vulnerable non-target species (Halpern \& Warner 2002). Green turtle foraging sites have been described as potential indicators of quality tropical coastal marine ecosystems, therefore useful in the proposal of MPAs (Scott et al., 2012). Much of Libya's coastline has so far escaped over-exploitation and degradation; total fisheries catch is an order of magnitude lower than that of neighbouring Egypt and Tunisia, and vast stretches remain relatively unpopulated (Haddoud \& Rawag, 2007). The rate of marine exploitation has accelerated, however, and implementation of conservation legislation has been delayed by political unrest (Badalamenti et al., 2011). The Gulf of Bomba (Fig. 2d site C), the most important green turtle foraging area identified here through satellite telemetry, is recognised as a biodiversity hotspot, and legislative framework for protection has been established through the Ain Gazala MPA (Badalamenti et al., 2011; see Fig. S1c for MPAs of the eastern Mediterranean). We recommend that the Gulf of Sirte (site B) also be investigated as a likely additional biodiversity hotspot, and thus a potential 
for MPA proposal. Protection of these two major foraging grounds should benefit a high proportion of the adult green turtle population in the Mediterranean. Site A at the Libya/ Tunisia border (as well as further offshore within the Gulf of Gabès shelf) is also a known year-round foraging site for male, female and juvenile loggerhead turtles from around six Mediterranean breeding populations (Broderick et al., 2007; Casale et al., 2007; Zbinden et al., 2011; Schofield et al., 2013); protection at this site would therefore afford benefits to both species. The green turtle foraging grounds at the Gulfs of Sirte (B), Bomba (C), Salum (D), Arab (E) and Tripoli, Lebanon (G) are also shared with foraging loggerheads (Broderick et al., 2007; Casale et al., 2007, 2013; Hochscheid et al., 2010; Schofield et al., 2013), although fewer individuals of the latter species have thus far been tracked to these sites.

Tracking studies targeting juvenile green turtles would be beneficial as the majority of bycaught turtles in the Mediterranean are small in size (Wallace et al., 2010), implying a higher degree of spatial overlap between fishing effort and habitat use of juveniles. Although bycatch data availability for the Mediterranean has a geographical bias to the western basin, the pattern in size-class may be consistent: a small-scale survey of coastal trawlers in Turkey (Mersin to İskenderun Bay) found that the majority of turtle bycatch was green turtle $(77 \%)$, and $80 \%$ of bycaught turtles were juveniles (Oruç, 2001). Additionally, analysis of dead stranded turtles and registered by-catch in northern Cyprus (Snape et al., 2013) and eastern Turkey (Türkozan et al., 2013) indicated that juvenile green and adult loggerhead turtles were at higher risk from local fisheries than adult green turtles.

Data from four of the individuals tracked in this study indicate that green turtles do not necessarily remain within a single foraging ground for the entirety of the non-breeding period, contrary to previous observations (Plotkin, 2003; Broderick et al., 2007). Transmitter deployments on turtles at foraging areas would be beneficial to determine the extent of this behaviour, to describe the timing of pre-nesting migrations and to confirm whether outbound breeding migrations match the return paths described here, all of which have implications for management of key migratory habitats. Tracks from Turkey and Syria have 
revealed two foraging bays that were not known from tracking efforts from Cyprus, despite close proximity and large sample size, demonstrating the importance of tracking from multiple sites. Tracking from Turkey in this study also highlights that as well as aspiring to large sample size (Schofield et al., 2013), it is advisable to collect tracking data across multiple years when building up a picture of dispersal patterns. This has previously been highlighted for leatherback turtles (Witt et al., 2011).

\section{Acknowledgments}

K.L.S. is funded by the European Social Fund. We thank the following for their support: Ecological Research Society (EKAD), Israel National Nature and Parks Authority (INNPA), Marine Turtle Conservation Project (MTCP), North Cyprus Department of Environmental Protection, seaturtle.org, Society for the Protection of Sea Turtles in North Cyprus (SPOT), Turkish Republic Ceyhan and Yumurtalık District Governorates; and for funding: ARCHELON, Apache, Baku-Tbilisi-Ceyhan Crude Oil Pipeline Company, British Chelonia Group, BP Egypt, the British High Commission and British Residents Society of North Cyprus, Darwin Initiative, Erwin Warth Foundation, Friends of SPOT, INNPA, Kuzey Kıbrıs Turkcell, NERC, Marine Conservation Society Sea Turtle Conservation Fund, MEDASSET UK. 


\section{References}

Alfaro-Shigueto J., Mangel J.C., Dutton P.H., Seminoff J.A., \& Godley B.J. (2012) Trading information for conservation: a novel use of radio broadcasting to reduce sea turtle bycatch. Oryx, 46, 332-339.

Badalamenti F., Ben Amer I., Dupuy De La Grandrive R., Foulquie M., Milazzo M., Sghaier Y.R., Gomei M., \& Limam A. (2011) Scientific field survey report for the development of Marine Protected Areas in Libya. $31 \mathrm{pp}$.

Bjorndal K.A. (1997) Foraging ecology and nutrition of sea turtles. The Biology of Sea Turtles (ed. by P.L. Lutz and J.A. Musick), pp. 199-231. CRC Press, Boca Raton, Florida, USA.

Block B.A., Jonsen I.D., Jorgensen S.J., Winship A.J., Shaffer S.A., Bograd S.J., Hazen E.L., Foley D.G., Breed G.A., Harrison A.-L., Ganong J.E., Swithenbank A., Castleton M., Dewar H., Mate B.R., Shillinger G.L., Schaefer K.M., Benson S.R., Weise M.J., Henry R.W., \& Costa D.P. (2011) Tracking apex marine predator movements in a dynamic ocean. Nature, 475, 86-90.

Blumenthal J.M., Solomon J.L., Bell C.D., Austin T.J., Ebanks-Petrie G., Coyne M.S., Broderick A.C., \& Godley B.J. (2006) Satellite tracking highlights the need for international cooperation in marine turtle management. Endangered Species Research, 7, 1-11.

Broderick A.C., Coyne M.S., Fuller W.J., Glen F., \& Godley B.J. (2007) Fidelity and over-wintering of sea turtles. Proceedings of the Royal Society B, 274, 1533-1538.

Canbolat A.F. (2004) A review of sea turtle nesting activity along the Mediterranean coast of Turkey. Biological Conservation, 116, 81-91.

Cardona L., Campos P., Levy Y., Demetropoulos A., \& Margaritoulis D. (2010) Asynchrony between dietary and nutritional shifts during the ontogeny of green turtles (Chelonia mydas) in the Mediterranean. Journal of Experimental Marine Biology and Ecology, 393, 83-89.

Casale P. (2011) Sea turtle by-catch in the Mediterranean. Fish and Fisheries, 12, 299-316.

Casale P., Freggi D., Basso R., Vallini C., \& Argano R. (2007) A model of area fidelity, nomadism, and distribution patterns of loggerhead sea turtles (Caretta caretta) in the Mediterranean Sea. Marine Biology, 152, 1039-1049.

Casale P., Freggi D., Cinà A., \& Rocco M. (2013) Spatio-temporal distribution and migration of adult male loggerhead sea turtles (Caretta caretta) in the Mediterranean Sea: further evidence of the importance of neritic habitats off North Africa. Marine Biology, 160, 703-718.

Chaloupka M., Bjorndal K.A., Balazs G.H., Bolten A.B., Ehrhart L.M., Limpus C.J., Suganuma H., Troëng S., \& Yamaguchi M. (2008) Encouraging outlook for recovery of a once severely exploited marine megaherbivore. Global Ecology and Biogeography, 17, 297-304.

Coyne M.S. \& Godley B.J. (2005) Satellite Tracking and Analysis Tool (STAT): an integrated system for archiving, analyzing and mapping animal tracking data. Marine Ecology Progress Series, 301, 1-7.

Eckert S.A. \& Sarti L. (1997) Distant fisheries implicated in the loss of the world's largest leatherback nesting population. Marine Turtle Newsletter, 78, 2-7. 
EJF (2007) Illegal driftnetting in the Mediterranean. Environmental Justice Foundation, London.

Fossette S., Witt M., Miller P., Nalovic M.A., Albareda D., Almeida A.P., Broderick A., Chacon-Chaverri D., Coyne M.S., Domingo A., Eckert S., Evans D., Fallabrino A., Ferraroli S., Formia A., Giffoni B., Hays G.C., Hughes G., Kelle L., Leslie A., Lopez-Mendilaharsu M., Luschi P., Prosdocimi L., Rodriguez-Heredia S., Turny A., Verhage S., \& Godley B.J. (2014) Pan-Atlantic analysis of the overlap of a highly migratory species, the leatherback turtle, with pelagic longline fisheries. Proceedings of the Royal Society B, 281, 20133065.

Gerosa G. \& Casale P. (1999) Interaction of marine turtles with fisheries in the Mediterranean.

Mediterranean Action Plan - UNEP Regional Activity Centre for Specially Protected Areas. 31 pp.

Gilman E., Zollett E., Beverly S., Nakano H., Davis K., Shiode D., Dalzell P., \& Kinan I. (2006a) Reducing sea turtle by-catch in pelagic longline fisheries. Fish and Fisheries, 7, 1-22.

Gilman E.L., Dalzell P., \& Martin S. (2006b) Fleet communication to abate fisheries bycatch. Marine Policy, 30, 360-366.

Godley B.J., Richardson S., Broderick A.C., Coyne M.S., Glen F., \& Hays G.C. (2002) Long-term satellite telemetry of the movements and habitat utilisation by green turtles in the Mediterranean. Ecography, 25, 352-362.

Haddoud D.A. \& Rawag A.A. (2007) Marine Protected Areas along Libyan coast. MedSudMed Technical Documents No. 3, pp 23-31.

Halpern B.S. \& Warner R.R. (2002) Marine reserves have rapid and lasting effects. Ecology Letters, 5, 361366.

Hays G.C., Luschi P., Papi F., del Seppia C., \& Marsh R. (1999) Changes in behaviour during the inter-nesting period and post-nesting migration for Ascension Island green turtles. Marine Ecology Progress Series, 189, 263-273.

Hobday A.J., Hartog J.R., Spillman C.M., Alves O., \& Hilborn R. (2011) Seasonal forecasting of tuna habitat for dynamic spatial management. Canadian Journal of Fisheries and Aquatic Sciences, 68, 898-911.

Hobday A.J., Hartog J.R., Timmiss T., \& Fielding J. (2010) Dynamic spatial zoning to manage southern bluefin tuna (Thunnus maccoyii) capture in a multi-species longline fishery. Fisheries Oceanography, 19, 243253.

Hochscheid S., Bentivegna F., Hamza A., \& Hays G.C. (2010) When surfacers do not dive: multiple significance of extended surface times in marine turtles. Journal of Experimental Biology, 213, 1328-1337.

Hornell J. (1935) Report on the fisheries of Palestine. Crown Agents for the Colonies, on behalf of the Government of Palestine, London.

Howell E.A., Kobayashi D.R., Parker D.M., Balazs G.H., \& Polovina J.J. (2008) TurtleWatch: a tool to aid in the bycatch reduction of loggerhead turtles Caretta caretta in the Hawaii-based pelagic longline fishery. Endangered Species Research, 5, 267-278. 
Kanai Y., Ueta M., Germogenov N., Nagendran M., Mita N., \& Higuchi H. (2002) Migration routes and important resting areas of Siberian cranes (Grus leucogeranus) between northeastern Siberia and China as revealed by satellite tracking. Biological Conservation, 106, 339-346.

Katsanevakis S., Levin N., Coll M., Giakoumi S., Shkedi D., Mackelworth P., Levy R., Velegrakis A., Koutsoubas D., Caric H., Brokovich E., Öztürk B., \& Kark S. (2015) Marine conservation challenges in an era of economic crisis and geopolitical instability: The case of the Mediterranean Sea. Marine Policy, 51, 3139.

Lewison R., Crowder L., Read A., \& Freeman S. (2004) Understanding impacts of fisheries bycatch on marine megafauna. Trends in Ecology \& Evolution, 19, 598-604.

Limpus C.J., Miller J.D., Paramenter C.J., Reimer D., McLachLan N., \& Webb R. (1992) Migration of green (Chelonia mydas) and loggerhead (Caretta caretta) turtles to and from eastern Australian rookeries. Wildlife Research, 19, 347-357.

Lipkin Y., Beer S., \& Zakai D. (2003) The seagrasses of the eastern Mediterranean and the Red Sea. World Atlas of Seagrasses (ed. by E.P. Green and F.T. Short), pp. 65-73. University of California Press, London.

Luschi P., Hays G.C., Del Seppia C., Marsh R., \& Papi F. (1998) The navigational feats of green sea turtles migrating from Ascension Island investigated by satellite telemetry. Proceedings of the Royal Society $B$, 265, 2279-2284.

Maxwell S.M., Breed G.A., Nickel B.A., Makanga-Bahouna J., Pemo-Makaya E., Parnell R.J., Formia A., Ngouessono S., Godley B.J., Costa D.P., Witt M.J., \& Coyne M.S. (2011) Using satellite tracking to optimize protection of long-lived marine species: olive ridley sea turtle conservation in Central Africa. PLOS ONE, 6, e19905.

Moncada F.G., Hawkes L.A., Fish M.R., Godley B.J., Manolis S.C., Medina Y., Nodarse G., \& Webb G.J.W. (2012) Patterns of dispersal of hawksbill turtles from the Cuban shelf inform scale of conservation and management. Biological Conservation, 148, 191-199.

Nada M. \& Casale P. (2011) Sea turtle bycatch and consumption in Egypt threatens Mediterranean turtle populations. Oryx, 45, 143-149.

Nada M.A., Boura L., Grimanis K., Schofield G., El-Alwany M.A., Noor N., Ommeran M.M., \& Rabia B. (2013) Egypt's Bardawil Lake: Safe haven or deadly trap for sea turtles in the Mediterranean? A report by MEDASSET, Suez Canal University and Nature Conservation Egypt. 79pp.

Oruç A. (2001) Trawl fisheries in the eastern Mediterranean and their impact on marine turtles. Zoology in the Middle East, 24, 119-125.

Panigada S., Zanardelli M., MacKenzie M., Donovan C., Mélin F., \& Hammond P.S. (2008) Modelling habitat preferences for fin whales and striped dolphins in the Pelagos Sanctuary (western Mediterranean Sea) with physiographic and remote sensing variables. Remote Sensing of Environment, 112, 3400-3412.

Plotkin P.T. (2003) Adult migrations and habitat use. The Biology of Sea Turtles II (ed. by P.L. Lutz, J.A. Musick, and J. Wyneken), pp. 225-241. CRC Press, Boca Raton, Florida, USA.

Rees A.F., Saad A., \& Jony M. (2008) Discovery of a regionally important green turtle Chelonia mydas rookery in Syria. Oryx, 42, 456-459. 
Sawyer H., Kauffman M.J., Nielson R.M., \& Horne J.S. (2009) Identifying and prioritizing ungulate migration routes for landscape-level conservation. Ecological Applications, 19, 2016-2025.

Schofield G., Dimadi A., Fossette S., Katselidis K.A., Koutsoubas D., Lilley M.K.S., Luckman A., Pantis J.D., Karagouni A.D., \& Hays G.C. (2013) Satellite tracking large numbers of individuals to infer population level dispersal and core areas for the protection of an endangered species. Diversity and Distributions, 19, 834-844.

Scott R., Hodgson D.J., Witt M.J., Coyne M.S., Adnyana W., Blumenthal J.M., Broderick A.C., Canbolat A.F., Catry P., Ciccione S., Delcroix E., Hitipeuw C., Luschi P., Pet-Soede L., Pendoley K., Richardson P.B., Rees A.F., \& Godley B.J. (2012) Global analysis of satellite tracking data shows that adult green turtles are significantly aggregated in Marine Protected Areas. Global Ecology and Biogeography, 21, 1053-1061.

Sella I. (1982) Sea Turtles in the Eastern Mediterranean and Northern Red Sea. Biology and Conservation of Sea Turtles: Proceedings of the World Conference on Sea Turtle Conservation, Washington, D. C., 26-30 November 1979. (ed. by K.A. Bjorndal), pp. 417-423. Smithsonian Institution, Washington, D.C.

Seminoff J. (2004) Chelonia mydas. IUCN Red List of Threatened Species. Version 2012.1 <www.iucnredlist.org>. Downloaded on 15 July 2012.

Seminoff J.A. \& Shanker K. (2008) Marine turtles and IUCN Red Listing: A review of the process, the pitfalls, and novel assessment approaches. Journal of Experimental Marine Biology and Ecology, 356, 52-68.

Shillinger G.L., Palacios D.M., Bailey H., Bograd S.J., Swithenbank A.M., Gaspar P., Wallace B.P., Spotila J.R., Paladino F. V, Piedra R., Eckert S.A., \& Block B.A. (2008) Persistent leatherback turtle migrations present opportunities for conservation. PLoS biology, 6, e171.

Snape R.T.E., Beton D., Broderick A.C., Çiçek B.A., Fuller W.J., Özden Ö., \& Godley B.J. (2013) Strand monitoring and anthropological surveys provide insight into marine turtle bycatch in small-scale fisheries of the eastern Mediterranean. Chelonian Conservation and Biology, 12, 44-55.

Stokes K.L., Fuller W.J., Godley B.J., Glen F., Hodgson D., Snape R.T., \& Broderick A.C. (2014) Detecting green shoots of recovery: the importance of long-term individual based monitoring of marine turtles. Animal Conservation, DOI:10.1111/acv.12128.

Türkecan O. \& Yerli S.V. (2011) Satellite tracking of adult green sea turtles from Turkey: a long distance diary. Marine Turtle Newsletter, 131, 38-41.

Türkozan O., Ozdilek S.Y., Ergene S., Ucar A.H., Sonmez B., Yilmaz C., Kacar Y., \& Aymak C. (2013) Strandings of loggerhead (Caretta caretta) and green (Chelonia mydas) sea turtles along the eastern Mediterranean coast of Turkey. Herpetological Journal, 23, 11-15.

Wallace B.P., Lewison R.L., McDonald S.L., McDonald R.K., Kot C.Y., Kelez S., Bjorkland R.K., Finkbeiner E.M., Helmbrecht S., \& Crowder L.B. (2010) Global patterns of marine turtle bycatch. Conservation Letters, 3, 131-142.

Witt M.J., Bonguno E.A., Broderick A.C., Coyne M.S., Formia A., Gibudi A., Mounguengui G.A.M., Moussounda C., NSafou M., Nougessono S., Parnell R.J., Sounguet G.-P., Verhage S., \& Godley B.J. (2011) Tracking leatherback turtles from the world's largest rookery: assessing threats across the South Atlantic. Proceedings of the Royal Society B, 278, 2338-47. 
Witt M.J., Broderick A.C., Johns D.J., Martin C., Penrose R., Hoogmoed M.S., \& Godley B.J. (2007) Prey landscapes help identify potential foraging habitats for leatherback turtles in the NE Atlantic. Marine Ecology Progress Series, 337, 231-243.

Zbinden J.A., Bearhop S., Bradshaw P., Gill B., Margaritoulis D., Newton J., \& Godley B.J. (2011) Migratory dichotomy and associated phenotypic variation in marine turtles revealed by satellite tracking and stable isotope analysis. Marine Ecology Progress Series, 421, 291-302.

Zydelis R., Lewison R.L., Shaffer S.A., Moore J.E., Boustany A.M., Roberts J.J., Sims M., Dunn D.C., Best B.D., Tremblay Y., Kappes M.A., Halpin P.N., Costa D.P., \& Crowder L.B. (2011) Dynamic habitat models: using telemetry data to project fisheries bycatch. Proceedings of the Royal Society B, 278, 3191-200.

\section{Supporting Information}

Additional supporting information may be found in the online version of this article:

Appendix S1. Nesting data sources for Table 1.

Table S1. Summary of satellite transmitter deployments and data.

Table S2. Summary of marine turtle bycatch data available for the eastern Mediterranean countries relevant to this study (modified from Casale, 2011).

Figure S1. Bathymetry, sea surface temperature, surface currents, fisheries Exclusive Economic Zones and Marine Protected Areas of the eastern Mediterranean.

\section{Biosketch}

Kimberley L. Stokes is a marine ecologist interested in research led conservation and is part of the Marine Turtle Research Group (MTRG). This work constituted part of her doctoral thesis with BJG and ACB at the University of Exeter. Further information about the MTRG can be found at http://www.seaturtle.org.uk/mtrg/.

Author contributions: ACB, BJG and KLS conceived the ideas; KLS, ACB, AFC, OC, WF, FG, YL, AFR, RTS and BJG collected the data; KLS analysed the data with contribution from IS; KLS, BJG and ACB led the writing, with contributions from all authors. 
Table 1. Green turtle nesting beaches of the Mediterranean. For data sources, see Appendix S1. Averages are means unless otherwise indicated (*).

\begin{tabular}{|c|c|c|c|c|c|c|c|c|c|}
\hline \multirow{2}{*}{$\begin{array}{l}\text { Country } \\
\text { Cyprus }\end{array}$} & \multirow[t]{2}{*}{ Beach name } & \multirow{2}{*}{$\begin{array}{l}\text { Max recorded } \\
\text { no. nests } \\
179\end{array}$} & \multirow{2}{*}{$\begin{array}{c}\text { Year of } \\
\max \\
2000\end{array}$} & \multirow{2}{*}{$\begin{array}{r}\begin{array}{c}\text { Min recorded } \\
\text { no. nests }\end{array} \\
38\end{array}$} & \multicolumn{2}{|c|}{$\begin{array}{l}\text { Average no. } \\
\text { nests/ year }\end{array}$} & \multirow{2}{*}{$\begin{array}{r}\begin{array}{r}\text { No. years } \\
\text { surveyed }\end{array} \\
8\end{array}$} & \multirow{2}{*}{$\begin{array}{c}\text { Source } \\
\text { (see Appendix S1) } \\
1\end{array}$} & \multirow[t]{2}{*}{ Tracks } \\
\hline & & & & & 104 & & & & \\
\hline & Alagadi & 236 & 2013 & 8 & 66 & & 21 & 1,2 & 21 \\
\hline & Akamas Peninsula & 114 & 2004 & 9 & 48 & & 20 & 3 & \\
\hline & South Karpaz & 107 & 1994 & 35 & 64 & & 7 & 1 & \\
\hline & West Coast & 125 & 2012 & 4 & 49 & & 21 & 1,2 & \\
\hline & North Coast (excluding Alagadi) & 37 & 2004 & 0 & 16 & & 21 & 1,2 & 1 \\
\hline & Akrotiri peninsula & 7 & 1999, 2000 & 0 & 5 & & 5 & 4 & \\
\hline \multirow[t]{14}{*}{ Turkey } & Akyatan & 735 & 1998 & 108 & 223 & $*$ & 11 & $1,5-16$ & \\
\hline & Samandağ & 440 & 2006 & 1 & 44 & $*$ & 11 & $1,5,8,10,14,16-21$ & \\
\hline & Kazanlı & 403 & 2004 & 73 & 164 & $*$ & 10 & $1,5,8,10,16,18,19,22-28$ & \\
\hline & Sugözü & 213 & 2004 & 213 & 213 & & 1 & 16,29 & \\
\hline & Alata & 198 & 2006 & 20 & 128 & $*$ & 4 & $16,30,31$ & \\
\hline & Göksu & 20 & 1991 & 0 & 13 & $*$ & 7 & $1,5,8,14,32-35$ & \\
\hline & Yumurtalık & 15 & 1988 & 1 & 3 & $*$ & 3 & $5,14,16,17,36$ & 8 \\
\hline & Tuzla & 9 & 2006 & 4 & 9 & $*$ & 3 & $1,14,16,17,19,36$ & \\
\hline & Belek & 8 & 1998,2000 & 1 & 4 & $*$ & 8 & $1,5,8,14,16,35,37-40$ & \\
\hline & Kumluca/ Fenike & 7 & 1994 & 0 & 4 & $*$ & 2 & $1,8,14,16,37$ & \\
\hline & Ağyatan & 4 & 1996 & 0 & 3 & $*$ & 4 & $1,5,14-17,19$ & \\
\hline & Kızılot & 3 & 1993 & 0 & 1 & $*$ & 3 & $1,8,14,16,37,41$ & \\
\hline & Yelkoma & 3 & 1988 & 2 & 3 & $*$ & 2 & $1,5,14,16,17,19$ & \\
\hline & Patara & 2 & 2000 & 2 & 2 & & 1 & $1,14,16,42$ & \\
\hline \multirow[t]{5}{*}{ Syria } & Latakia & 273 & 2008 & 18 & 140 & & 6 & 43,44 & 1 \\
\hline & Banias & 15 & & 1 & 9 & & 6 & 44 & \\
\hline & Wadi Kandil & 13 & Data not & 1 & 7 & & 6 & 44 & \\
\hline & Ras el Basit & 11 & available & 0 & 4 & & 5 & 44 & \\
\hline & Um Toyour & 7 & & 0 & 3 & & 3 & 44 & \\
\hline Lebanon & El-Mansouri, Tyre Nature Reserve, El Abbasiyeh & 16 & 2004 & 0 & 7 & & 5 & $45-52$ & \\
\hline Israel & Nahariya, Gdor, Sharon, Ashkelon & 20 & 2006 & 0 & 8 & & 16 & $1,53,54$ & 3 \\
\hline Egypt & El Arish & 3 & 2000 & 0 & 1 & & 3 & $1,55-57$ & \\
\hline
\end{tabular}

* Medians are used where surveyed seasons are not consecutive 
Figures

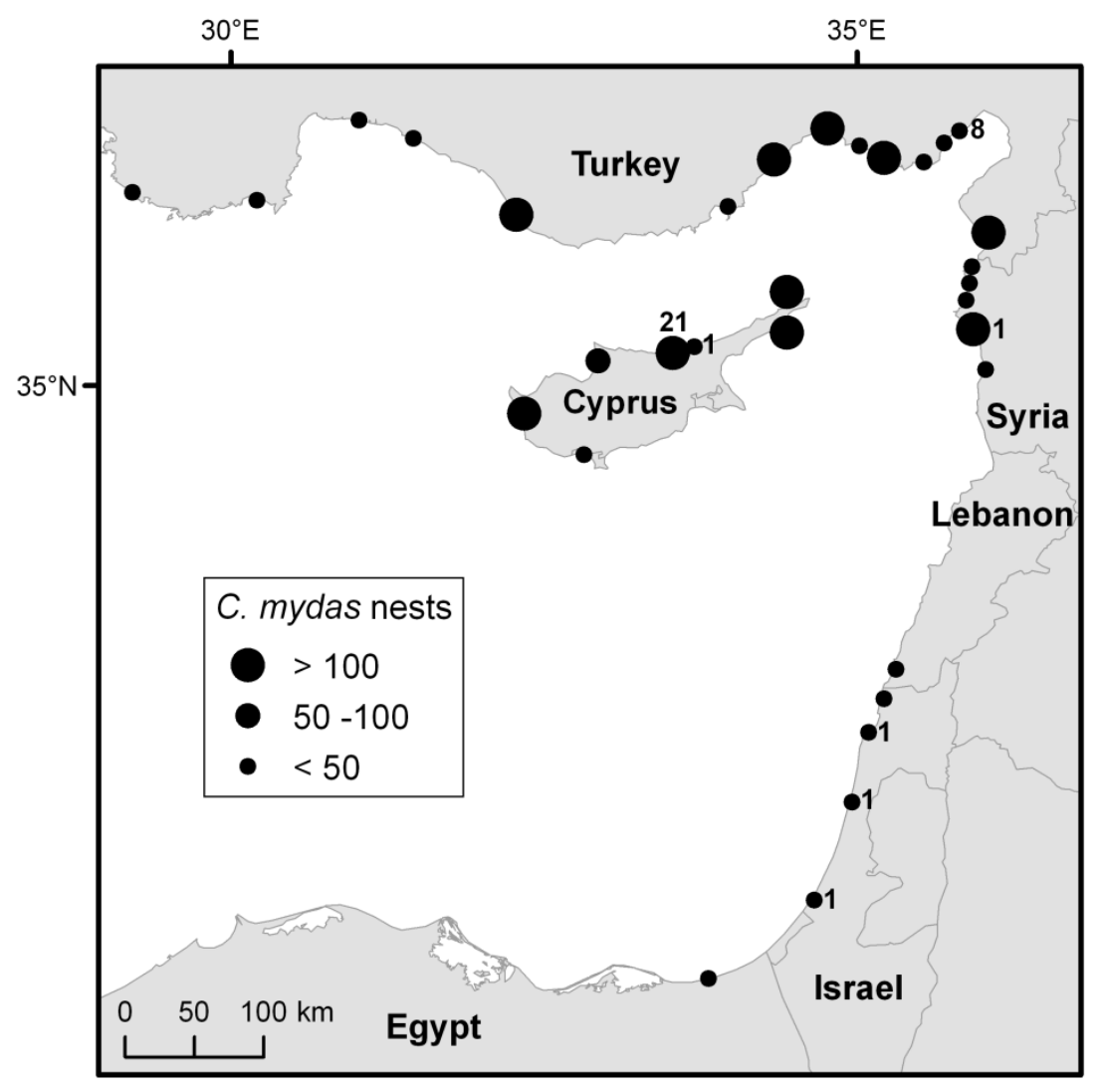



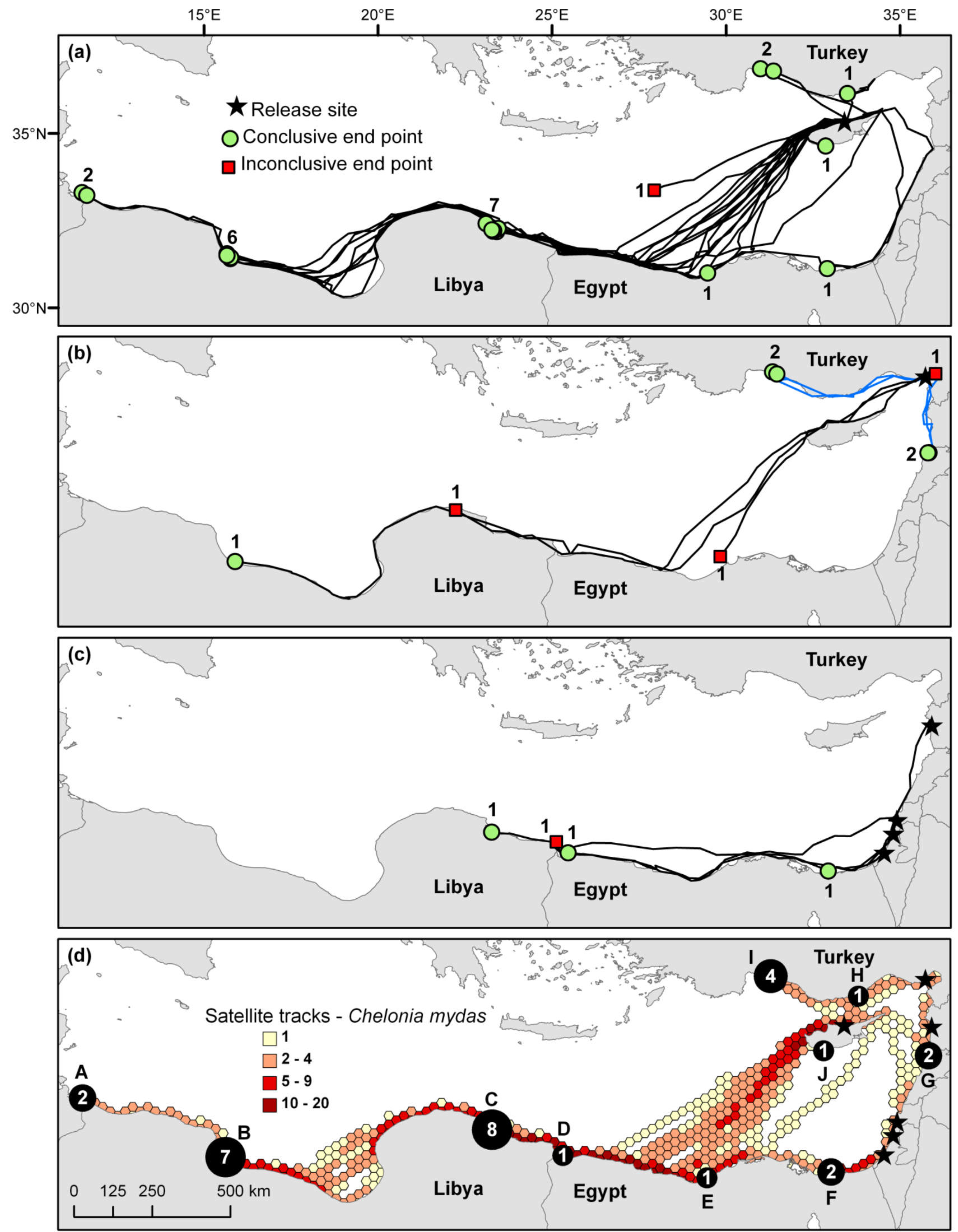


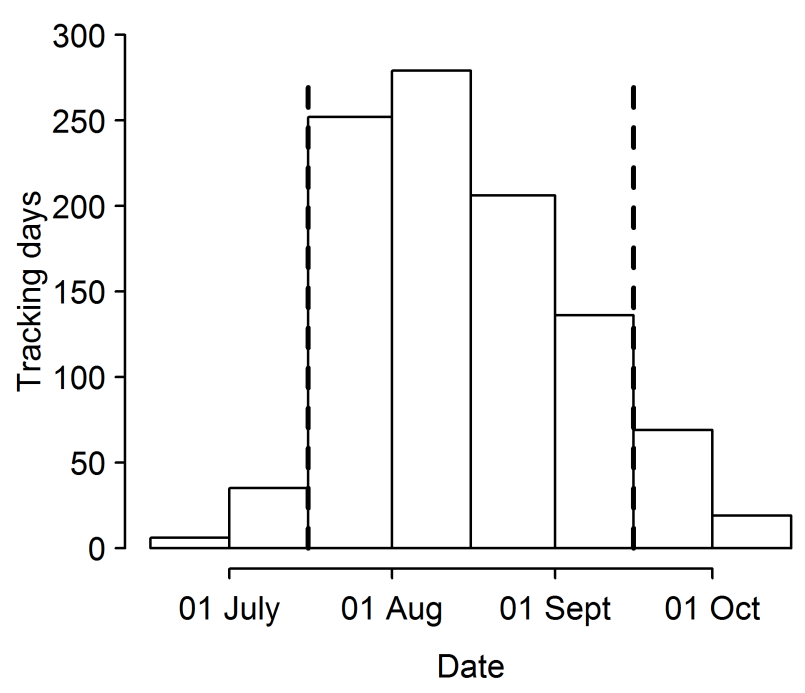




\section{Figure Legends}

Figure 1. Green turtle nesting beaches of the Mediterranean. Circle size represents magnitude of nesting at each site (maximum number of nests recorded in a season). Numbers indicate the sample size of individual females tracked from each nesting beach $(n=34)$. For nesting data and sources, see Table 1 and Appendix S1 in Supporting Information.

Figure 2. Post nesting green turtle satellite tracks from a) Cyprus $(n=22), b)$ Turkey $(n=8), c)$ Syria $(n=1)$ and Israel ( $n=3)$, and d) migratory corridor density map (conclusive tracks only; $n=29$ ). Numbers indicate the number of individuals tracked conclusively to each foraging ground. In panel $b$, tracks in blue are from the first year of tracking (2004) and those in black are from the second year of tracking (2005). Colour in panel d is indicative of the number of satellite tracks that pass though each hexagonal grid cell. Movements to secondary foraging grounds after prolonged stays in initial foraging grounds are not included. Letters in d) indicate the following foraging grounds: A - Libya/Tunisia border, B - Gulf of Sirte, C - Gulf of Bomba, D - Gulf of Salum, E - Gulf of Arab, F - Lake Bardawil, G - Tripoli, Lebanon, H - Erdemli, I - Gulf of Antalya, J - Episkopi Bay.

Figure 3. Seasonality of post-nesting Chelonia mydas migrations tracked in this study. Eighty seven percent of all migratory tracking days took place between $15^{\text {th }}$ July and $15^{\text {th }}$ September (dashed lines). Outbound breeding migrations are estimated to take place from April to June. 